\title{
The effectiveness of Solution Focused Brief Counseling to improve the self-concept of commercial sex workers in rehabilitation institutions
}

\author{
Arif Setiawan ${ }^{1}$, Yarmis Syukur ${ }^{1}$, Netrawati ${ }^{1}$ \\ ${ }^{1}$ Universitas Negeri Padang \\ ${ }^{*}$ Corresponding author, e-mail: arifsetiawan.arif11@gmail.com
}

\begin{abstract}
The life of the Indonesian people is a very complex life with various social problems that hit several communities. The existence of various social problems faced by the community makes them live an abnormal or inappropriate life such as the low economy in meeting the needs of life. Social problems are some conditions that arise from a society that cannot function properly, resulting in disappointment and suffering. In this case, those who often experience social problems are usually women, one of the people with social welfare problems, namely Commercial Sex Workers. Someone who works and acts in the field of prostitution is better known as a commercial sex worker. The practice of prostitution by sex workers causes several psychological impacts that refer to negative self-concepts, such as feeling of having low self-esteem in the eyes of the community, being inferior in front of many people, limiting themselves in community interactions, feeling depressed, relationship gaps with other family members. Based on the results of the study, there were 8 PSKs whose self-concept level was in the medium category with a percentage of $38.1 \%$, then 10 PSKs whose self-concept level was in the low category, namely $47.6 \%$. 2 PSKs whose selfconcept level was in the very low category, namely $9.5 \%$. So it can be concluded that the average self-concept of CSWs before being given treatment was in the medium and low categories. The research method used by the researcher is the experimental research method. The type of experimental research used by the researcher is a quasiexperimental (quasi-experimental). Quasi-experimental is a quasi-experiment that aims to predict the conditions that can be achieved through actual experiments, but there is no control and manipulation of all relevant variables. Based on the description above, it can be concluded that this study seeks to determine how high the self-concept of sex workers is
\end{abstract}

Keywords: Solution Focus Brief Counseling, Self-Concept, Commercial Sex Workers

How to Cite: Arif Setiawan, A., Syukur, Y., Netrawati, N. (2021). The effectiveness of Solution Focused Brief Counseling to improve the self-concept of commercial sex workers in rehabilitation institutions. International Journal of Applied Counseling and Social Sciences, 2 (2): pp. 168-174, DOI: https://doi.org/10.24036/005441ijaccs 
This is an open access article distributed under the Creative Commons 4.0 Attribution License, which permits unrestricted use, distribution, and reproduction in any medium, provided the original work is properly cited. @2021 by Author

\section{Introduction}

The practice of prostitution by sex workers causes several psychological impacts that refer to negative self-concepts, such as: feeling of having low self-esteem in the eyes of society, being inferior in front of many people, limiting themselves in community interactions, feeling depressed, relationship gaps with other family members, feeling dependent on others. people or things (eg cigarettes or alcohol), and depression. Whereas self-concept is an important part of personality, namely as a determinant of how a person behaves and behaves. If humans see themselves as incapable, helpless and other negative things, this will affect them in trying. Selfconcept greatly affects one's personality, with self-concept, every act or behavior of a person is based on the concept he formed to appear and behave in accordance with his selfconcept (Wulandari \& Susilawati, 2016)

One of the problems that is still problematic in Indonesia is the problem of prostitution which is increasingly rampant. The current increase in prostitution activities can be done both in person and online, and involves many groups, such as the general public, regional officials to the realm of teenagers. A person who works and acts in the field of prostitution is better known as a commercial sex worker (CSWs). Since ancient times, sex workers have always been criticized or condemned by society, because their behavior is not polite and is considered to pollute the sacredness of sex. They are referred to as people who violate moral, customary and religious norms.

The concept itself is an important part of human personality, which teaches individuals how to look thoroughly about him, including on capabilities, feelings experienced physical condition itself or the immediate environment, through approaches S F B C is expected to help provide solutions to problems experienced by prostitutes. In 2019 Quoted from padangkita.com it is known that the number of sex workers netted by the Padang City Civil Service Police unit has increased at the end of 2019. This number has increased by more than $100 \%$ when compared to the previous year. Based on data from the Padang City Civil Service Police Unit, at least 22 sex workers were caught throughout 2019, while the previous number of sex workers was only 9 people. Commercial sex workers who are better known as sex workers can be interpreted as misbehaving, disrespectful or failing to conform to moral norms. The term Commercial Sex Worker implies that the sale of sexual services can be carried out by women (men) as a form of work and a rational choice of women's freedom to do what she wants with her body to earn an income (Hamilton, 2016) .

The factors behind the emergence of CSWs according to (Kartono, 2009 ), are as follows: 1). There is a tendency to prostitute themselves in many women to escape the difficulties of life, and get pleasure through the short way. Lack of understanding, lack of education, and illiteracy that justifies prostitution. 2). There are abnormal sexual desires, not integrated in the personality, and sexual indulgence.3). Hysterical and hypersexual, so they do not feel satisfied having sex with one man or husband.4). Economic pressures, poverty factors, especially in an effort to get a good social status. 5). Curiosity of little girls and pubescent children on sex issues, 6). Invite friends from your village or town who have entered the world of prostitution first. 7). There is a normal sexual need, but the husband is not satisfied. 
The self-concept according to Calhoun and Acocella is an arrangement of hypothetical concepts that refers to a complex set of characteristics of a person's physical, behavioral, and psychological processes. According to William D. Brooks (Rakhmad, 2015) quoted by Jalaludin Rakhmad who stated that self-concept is an individual's perception of himself that is psychological and social as a result of interaction with other people. According to him, selfconcept is an individual's view of who the individual is and that can be obtained through information provided through information provided by other people to the individual. In line with that , Wahyu, Taufik. Netrawati , \& Ilyas, (2012) suggested that the self-concept basically contains a self-image which includes perceptions about oneself, feelings, beliefs, perceptions, values related to themselves. Changes that occur inside and outside themselves make them have a negative perception of themselves and affect the development of their selfconcept Wahyu, Taufik. Netrawati , \& Ilyas, (2012). Self-concept is "All of our perceptions of aspects of ourselves which include physical aspects, social aspects, and psychological aspects, which are based on our experiences and interactions with other people. Self-concept can be one of the factors in shaping the behavior displayed by adolescents, as stated by Elida Prayitno (in Yarmis, 2015)

SFBC (solution focus brief counseling) is one of the postmodern approach counseling techniques. This therapy is oriented towards solving the problem, not what the problem is. SFBC (solution focus brief counseling) was founded by two figures, namely Insoo Kim Berg and Steve De Shaver. The SFBC model requires a philosophical attitude in accepting clients where they are assisted in making solutions. Wiretna et al., (2020) describe a positive orientation to finding solutions and improving human life from focusing on the pathological parts of the problem and amazing changes can occur quickly. Because clients often come to counselors with problem-oriented statements, even few of the solutions they are considering are wrapped up in the power of problem orientation. SFBC counselors challenge counselees' statements with optimistic conversations that refer to their belief in achievement by using goals from various angles (Sklare, 2014)

\section{Method}

The research method used by the researcher is the experimental research method. The type of experimental research used by the researcher is a quasi-experimental (quasiexperimental ). According to Arifin et al. (2020) quasi-experimental is a quasi-experiment that aims to predict the state that can be achieved through actual experiments, but there is no control and manipulation of all relevant variables.

Based on the description above, it can be concluded that this study seeks to determine how high the self-concept of sex workers is. As for the sample in this study as many as 21 people. The data collection technique used in this study was an instrument, the instrument of this research was a questionnaire on the concept of sex workers with a Likert scale.

Arikunto, (2010) Questionnaires are a number of written questions that are used to obtain information from respondents in terms of reports about themselves or things they know. The distributed questionnaires are designed according to the needs and distributed to the respondents. So the questionnaire is a set of questions that must be answered by the respondent in writing which is used to obtain various information directly given by the respondent. The type of questionnaire used by the researcher is a Likert scale questionnaire 
which has five alternative answers where the questionnaire provides a choice of statements in the form of a checklist in one of the answers. Iskandar \& Rizal, (2018) stated that the question or statement to be answered by the respondent is in the form of a Likert scale which has a gradation of very positive and very negative expressed through words.

\section{Results and Discussion}

The results of the PSK self-concept data were carried out to find out the initial picture of the condition of the self-concept before being given treatment. To find out the condition of the self-concept pretest before being given treatment with group counseling services using a solution focused brief counseling approach, it can be seen that the description of the selfconcept level of CSWs is presented in table 1 , below.

Table 1. Overall Data Overview of PSK self-concept ( Pre Test)

\begin{tabular}{cccc}
\hline Category & Interval Score & F & \% \\
\hline Very high & 166 & 0 & 0.0 \\
Tall & $134-165$ & 1 & 4.8 \\
Currently & $102-133$ & 8 & 38.1 \\
Low & $70-101$ & 10 & 47.6 \\
Very low & 69 & 2 & 9.5 \\
\hline & TOTAL & $\mathbf{2 1}$ & $\mathbf{1 0 0}$ \\
\hline
\end{tabular}

From the table above, it is known that there is 1 PSK whose self-concept level is in the high category with a percentage of $4.8 \%$, then 8 CSWs whose self-concept level is in the medium category, which is $38.1 \%$. there are 10 prostitutes whose level of self-concept is in the low category with a percentage of $47.6 \%$. there are 2 sex workers whose selfconcept level is in the very low category with a percentage of $9.5 \%$. So it can be concluded that the average self-concept of sex workers before being given treatment is in the medium and low categories.

Table 2 . Overview Of Sub-Variable Self-Concept Data

\begin{tabular}{|c|c|c|c|c|c|c|c|c|c|c|c|}
\hline \multirow[t]{3}{*}{ No } & \multirow[t]{3}{*}{ Sub Variable } & \multicolumn{10}{|c|}{ Category } \\
\hline & & \multicolumn{2}{|c|}{ ST } & \multicolumn{2}{|c|}{$\mathbf{T}$} & \multicolumn{2}{|c|}{$S$} & \multicolumn{2}{|c|}{$\mathbf{R}$} & \multicolumn{2}{|c|}{ SR } \\
\hline & & $\mathrm{F}$ & $\%$ & $\mathrm{~F}$ & $\%$ & $\mathrm{~F}$ & $\%$ & $\mathrm{~F}$ & $\%$ & $\mathrm{~F}$ & $\%$ \\
\hline 1 & $\begin{array}{l}\text { Basic self } \\
\text { concept }\end{array}$ & - & - & - & - & 2 & 9.5 & 19 & 90.5 & - & - \\
\hline 2 & $\begin{array}{l}\text { Social self } \\
\text { concept }\end{array}$ & - & - & - & - & - & - & 21 & 100 & - & - \\
\hline 3 & $\begin{array}{l}\text { Ideal self } \\
\text { concept }\end{array}$ & - & - & - & - & - & - & 21 & 100 & - & - \\
\hline \multicolumn{12}{|c|}{ Frequency $(\mathrm{N}=21)$} \\
\hline
\end{tabular}

From table 5 above, it can be seen that on the basic self-concept there are 19 people whose level of self-concept is in the low category with a percentage of $90.5 \%$, there are 2 people whose level of self-concept is in the medium category with a percentage of $9.5 \%$, then it is known on the social self-concept of 21 prostitutes whose level of self-concept is in the low 
category with a percentage of $100.0 \%$, on the ideal self-concept of 21 people whose level of self-concept is in the low category with a percentage of $100.0 \%$, so it can be concluded that the average PSK's self-concept before being given treatment on the basic, social and ideal selfconcept variables were in the low category.

Table 3 . Overview Data Overall Pre Test

\begin{tabular}{lcccc}
\hline \multicolumn{5}{c}{ Frequency $\mathbf{( N = 1 2 )}$} \\
\hline Overall Data & Category & Interval & F & $\mathbf{\%}$ \\
& Very high & 163 & - & - \\
& Tall & $132-162$ & - & - \\
& Currently & $101-131$ & 7 & 63.64 \\
& Low & $70-100$ & 5 & 45.45 \\
& Very low & 69 & - & - \\
\hline & & \multicolumn{3}{c}{} \\
\hline
\end{tabular}

From the table above, it is known that there are 7 sex workers whose level of self-concept is in the medium category with a percentage of $63.62 \%$, then 5 people whose level of selfconcept is in the medium category, which is $45.4 \%$. So it can be concluded that the average PSK's self-concept before being given treatment was in the medium and low categories.

Table 4 . Data overview Post? Est Concept Self-PSK Sub Variables

\begin{tabular}{|c|c|c|c|c|c|c|c|c|c|c|c|}
\hline \multirow[t]{3}{*}{ No } & Sub Variable & \multicolumn{10}{|c|}{ Category } \\
\hline & & \multicolumn{2}{|c|}{ ST } & \multicolumn{2}{|c|}{$\mathrm{T}$} & \multicolumn{2}{|c|}{$S$} & \multicolumn{2}{|c|}{$\mathbf{R}$} & \multicolumn{2}{|c|}{ SR } \\
\hline & & $\mathbf{F}$ & $\%$ & $\mathbf{F}$ & $\%$ & $\mathbf{F}$ & $\%$ & $\mathbf{F}$ & $\%$ & $\mathbf{F}$ & $\%$ \\
\hline 1 & $\begin{array}{l}\text { Basic self } \\
\text { concept }\end{array}$ & - & - & - & - & 7 & 63.6 & 5 & $\begin{array}{c}45 \\
4\end{array}$ & - & - \\
\hline 2 & $\begin{array}{l}\text { Social self } \\
\text { concept }\end{array}$ & - & - & - & - & 7 & 63.6 & 5 & 45.4 & - & - \\
\hline 3 & $\begin{array}{l}\text { Ideal self } \\
\text { concept }\end{array}$ & - & - & - & - & 5 & 45.4 & 7 & 63.6 & - & - \\
\hline \multicolumn{12}{|c|}{ Frequency $(\mathrm{N}=12)$} \\
\hline
\end{tabular}

From the table above, it can be seen that in the basic self-concept there are 7 people whose level of self-concept is in the medium category with a percentage of $63.6 \%, 5$ people whose level of self-concept is in the low category with a percentage of $45.5 \%$, then it is known on the self-concept 7 people whose level of self-concept is in the medium category with a percentage of $63.6 \%, 5$ people whose level of self-concept is in the low category with a percentage of $45.5 \%$. In the ideal self- concept 5 people whose level of self-concept is in the medium category with a percentage of $45.5 \%$. then 7 people whose level of self-concept is in the low category with a percentage of $63.6 \%$. So it can be concluded that the average self-concept of sex workers before being given treatment on the basic, social and ideal self-concept variables were in the medium and low categories. 
Table 5 . Post Test Data Overview of PSK's self-concept

\begin{tabular}{|c|c|c|c|c|}
\hline \multicolumn{5}{|c|}{ Frequency $(\mathrm{N}=12)$} \\
\hline \multirow[t]{6}{*}{ Overall Data } & Category & interval & $\mathrm{F}$ & $\%$ \\
\hline & Very high & 163 & 0 & 0 \\
\hline & Tall & $132-162$ & 10 & 90.9 \\
\hline & Currently & $101-131$ & 2 & 18.2 \\
\hline & Low & $70-100$ & 0 & 0 \\
\hline & Very low & 69 & 0 & 0 \\
\hline \multicolumn{2}{|c|}{ Total } & \multicolumn{2}{|c|}{12} & \\
\hline
\end{tabular}

From table 8 , it is known that 10 people whose level of self-concept is in the high category with a percentage of $90.8 \%$, then 2 people whose level of self-concept is in the medium category, namely $18.2 \%$. So it can be concluded that the average self-concept of sex workers after being given treatment is in the high and medium categories.

Table 7. Overview of Post-Test Data on Sub-Variable PSK Self- Concept

\begin{tabular}{|c|c|c|c|c|c|c|c|c|c|c|c|}
\hline \multirow[t]{3}{*}{ No } & Sub Variable & \multicolumn{10}{|c|}{ Category } \\
\hline & & \multicolumn{2}{|c|}{ ST } & \multicolumn{2}{|c|}{$\mathrm{T}$} & \multicolumn{2}{|c|}{ S } & \multicolumn{2}{|c|}{$\mathbf{R}$} & \multicolumn{2}{|c|}{ SR } \\
\hline & & F & $\%$ & F & $\%$ & $\mathbf{F}$ & $\%$ & $\mathbf{F}$ & $\%$ & $\mathbf{F}$ & $\%$ \\
\hline 1 & $\begin{array}{l}\text { Basic } \\
\text { Self Concept }\end{array}$ & 1 & 9.01 & 5 & 45.4 & 6 & 54.5 & - & - & - & - \\
\hline 2 & $\begin{array}{l}\text { Social } \\
\text { Self- Concept } 1\end{array}$ & - & - & 10 & 90.9 & 1 & 9.01 & 1 & 9.01 & - & - \\
\hline 3 & $\begin{array}{l}\text { Ideal } \\
\text { Self Concept }\end{array}$ & 1 & 9.01 & 10 & 90.9 & 1 & 9.01 & - & - & - & - \\
\hline & & & & & cy $(\Lambda$ & & & & & & \\
\hline
\end{tabular}

From the table above, it can be seen that in the basic self-concept there is 1 person whose level of self-concept is in the very high category with a percentage of $9.09 \%, 5$ people whose level of self-concept is in the high category with a percentage of $45.5 \%, 6$ people whose level of self-concept is in the high category with a percentage of $45.5 \%$. self-concept is in the medium category with a percentage of $54.5 \%$, then it is known on the social self-concept of 10 people whose level of self-concept is in the high category with a percentage of $90 . \%, 1$ person whose level of self-concept is in the medium category with a percentage of $9.09 \% .1$ people whose level of self-concept is in the low category with a percentage of $9.09 \%$. In the ideal selfconcept 1 person whose level of self-concept is in the very high category with a percentage of $9.09 \%$.. then 10 people whose level of self-concept is in the high category with a percentage of $90.9 \% .1$ person whose self-concept level is in the medium category with a percentage of $9.09 \%$ So it can be concluded that the average self-concept of sex workers after being given treatment on the basic, social and ideal self-concept variables is in the high category.

\section{Conclusion}

Based on the description of the data above, it can be concluded that group counseling services with a solution focused brief counseling approach are effective in improving the self- 
concept of CSWs. This effectiveness is involved from the total number of analyzes carried out in which the score of the CSWs self-concept on self-concept has increased. Thus, the use of a solution focused brief counseling approach in group counseling services makes its implementation easy, creative, and fun. Based on the results of the data description above, it can be concluded that group counseling services with a solution focused brief counseling approach can improve the self-concept of CSWs.

\section{References}

Arifin, S., Wahyudin, W., \& Herman, T. (2020). The effects of contextual group guided discovery learning on students' mathematical understanding and reasoning. Prima Edukasia Journal , 8 (2), 106-114.

Arikunto, S. (2010). Research procedures: a practical approach . Rineka Cipta.

Calhoun, JP Acocella, (1995). Psychology of adjustment and human relationships . Semarang: IKIP Semarang Press.

Hamilton, DP (2016). The adverse effects of stressors on novice teachers in an urban public elementary school: An action research study . Capella University.

Iskandar, A., \& Rizal, M. (2018). Analysis of the quality of the questions in higher education based on the TAP application. Journal of Educational Research And Evaluation , 22 (1), 1223.

Jalaluddin, R. (2015). (ed 30). Communication psychology. Bandung: Youth Rosda Karya.

Kartono, K. (2009). Social pathology . Jakarta: King Guardian of the Press.

Padangkita.com (2019). The Padang PP Satpol secures dozens of teenagers from the inn. (Online) https://padangkita.com .

Susetyo, DB, \& Sudiantara, Y. (2015). Self-concept in commercial sex workers. Psychodimensia , 14 (2), 27-40.

Sklare, GB (2014). Brief counseling that works: A solution-focused therapy approach for school counselors and other mental health professionals. Corwin Press. Law No. 21 of 2007 concerning: Eradication of the crime of trafficking in persons.

Wahyu, S., Taufik, T., \& Ilyas, A. (2012). Self-concept and problems experienced by people infected with HIV/AIDS. Counselor , 1 (2), 25-33.

Wiretna, CD, Saputra, WNE, Muarifah, A., \& Barida, M. (2020). Effectiveness of solutionfocused brief counseling to reduce online aggression of students. Universal Journal of Educational Research , 8 (3), 1092-1099.

Wulandari, AR, \& Susilawati, LKPA (2016). The role of self-acceptance and social support on the self-concept of adolescents living in orphanages in Bali. Udayana Journal of Psychology , 3 (3), 509-518.

Yusu f, A. M. ( 2013 ). Me todologi p e ne Litian kuantitat if, kua litatif, and pene Litian p eng e mbangan. $\mathrm{P}$ a d a $\mathrm{n}$. UNP P ress. 